\title{
ENERGY EFFICIENCY OF WORLD'S LEADING COPPER PRODUCERS
}

\author{
V.V. KRIVOROTOV ${ }^{1,2}$, A.V. KALINA ${ }^{1,2}$, N.V. STARODUBETS ${ }^{1,2}$, A.I. SAVELEVA ${ }^{1}$, \\ S.E. ERYPALOV 3 \\ ${ }^{1}$ Ural Federal University, Russia \\ ${ }^{2}$ Institute of Economics, Ural Branch of the Russian Academy of Sciences, Russia \\ ${ }^{3}$ Ural Mining and Metallurgical Company, Russia
}

\begin{abstract}
This paper provides an overview of the leading role that energy efficiency plays in the development of modern socio-economic systems, which serve as the foundation for building green economies. The main purpose of the paper is to develop a methodological toolkit for assessing energy efficiency of large industrial complexes and test it on the world's largest metallurgical complexes. The central object of the research is the Ural Mining and Metallurgical Company (UMMC), which mainly specializes in the production of copper and copper-based products. The study follows a comparative analysis of a set of preliminary selected energy efficiency indicators obtained from UMMC with those of the world's leading copper manufacturers and copper-based products.

At the same time, in accordance with the methodical approach, it is proposed to divide the energy efficiency indicators of an industrial complex into three levels: the level of an industrial complex as a whole (1); the level of certain types of products manufactured in the industrial complex (2); the level of the technological process (3).

To obtain summarized (synthetic) energy efficiency estimates of the industrial complex, the hierarchy analysis method has been proposed. For the comparative analysis of energy efficiency indicators of UMMC, the authors chose the following companies: Norilsk Nickel and Russian Copper Company and leading world companies, such as Glencore Xstrata Plc (Switzerland), Codelco (Chile), KGHM Polska Miedz SA (Poland), and Vedanta Resources (India).

The obtained results revealed that UMMC strongly lags behind in a number of key energy efficiency indicators. During 2010-2016, a negative trend was observed in the majority of UMMC enterprises. The results also showed the practical applicability of the given methodical approach and the possibility of its wide use in solving energy efficiency problems of Russian industrial complexes for their strategic development.
\end{abstract}

Keywords: copper producers, energy efficiency, energy efficiency indicators, green and low-carbon economy, industrial complex.

\section{INTRODUCTION}

Today, humanity is facing a difficult task of ensuring economic development while maintaining the quality of the environment and reducing the rate of consumption of non-renewable resources [1-2]. To deal with this challenge, developed and developing countries are introducing a green economy model to ensure sustainable development and allow future generations to meet their needs. According to the United Nations Environment Programme (UNEP), green economy is 'one that results in improved human well-being and social equity, while significantly reducing environmental risks and ecological scarcities' [3]. As pointed out in the work paper of the United Nations Conference on Sustainable Development (UNCSD) 'The Future We Want' [4], the main features of a green economy model are resource efficiency, low carbon emissions, preservation and enhancement of natural capital assets, reduction of environmental pollution, and growth in income and employment. These features, along with the ways of transition to a green economy and their benefits, challenges, and risks, are largely discussed in the paper [5-7]. It is noted that one of the essential elements in 
a green growth strategy is the efficient use of natural resources, including the introduction of energy-efficient technologies, which actually makes possible decoupling the use of non-renewable energy resources from economic growth [8].Thus, it becomes clear why often green growth is associated with a decrease in the rate of greenhouse gas emissions [9-11] and green economy is related to low-carbon economy [12-14].

If energy consumption across the world is analyzed by sector, according to [15], industrial complexes play a leading role. So their energy efficiency management needs to be studied in detail.The high proportion of energy-intensive enterprises in the Russian industry, such as ferrous and non-ferrous metallurgy, oil refining, and chemicals, leads to a high level of energy intensity of both gross domestic product and specific types of products. Energy intensity, being one of the indicators of energy efficiency, has a great impact on the competitiveness of industrial products in international markets. Since the energy intensity of the Russian economy today is two to three times higher than in developed countries [16], making Russian industrial complexes globally competitive by pushing them to achieve comparable values of global energy efficiency is closely linked with the implementation of a low-carbon energy-efficient development strategy [17].

Metallurgical complexes are the most energy-intensive in Russia's modern economy. To transform Russia into a green economy, making these complexes energy-efficient would make a significant contribution. Therefore, research and management issues of energy efficiency gain a high scientific and practical importance.

\section{ANALYSIS OF MODERN APPROACHES TO ENERGY EFFICIENCY ASSESSMENT}

The term 'energy efficiency' is widely used to achieve various goals such as to reduce energy costs, reduce carbon dioxide emissions, and increase the reliability of energy supply, among others. At the same time, the term is dual in nature, since, on the one hand, it is an indicator of energy efficiency and, on the other hand, it is a development factor, because with the increase of production volumes, the amount of energy introduced into the system increases as well [18].

Today, there is no universal definition of energy efficiency in the scientific community. Accordingly, there is no single universal approach for the assessment of energy efficiency.

At the same time, the great majority of modern views of assessing energy efficiency promote a similar approach to evaluating the parameter for given research objects, namely, conducting an assessment of a pre-selected set of energy efficiency indicators and comparing obtained estimates with similar objects. However, in different approaches, energy efficiency indicators themselves as well as the principles and algorithms for conducting an assessment may significantly differ.

An analysis of scientific literature devoted to the study of energy efficiency of production processes shows that today experts use two basic approaches to the assessment of an industrial complex's energy efficiency.

The first approach uses economic (cost) and technical and economic (physical) indicators together with indicators of energy-efficient production technologies. Such an approach to energy efficiency assessment is applied, for example, by the experts of World Energy Council and by other scientists [19-24].

Proponents of the second approach propose energy efficiency indicators, taking into account the type of activity (industrial and intra-sectoral), as well as indicators of energy intensity. This approach is implemented in the methodological recommendations of the Asia 
Pacific Research Center [25] and in the projects undertaken by the International Energy Agency [26-29], U.S. Department of Energy's Office of Energy Efficiency and Renewable Energy (EERE) [30], the French Agency for Environment and Energy Management ADEME and World Energy Council (database on energy efficiency indicators) [31].

Without making comparative analysis, the authors note that often both these approaches are used together. In this case, it is clear that both economic and technical indicators are required when framing indicators within the industry. Technical indicators are important in assessing separate units.

Since 1997, the International Energy Agency (IEA) has been developing groups of energy indicators to study the dynamics of energy consumption and analyze the factors affecting energy consumption and carbon dioxide emissions. The IEA was the first to suggest forming an energy efficiency pyramid (Fig. 1) made of energy efficiency indicators depending on their aggregation: from the most detailed at the pyramid's base to the most aggregated at the top.

The IEA approach is based on sectoral and structural indicators (activities within the industry). The more disaggregated an indicator is the clearer are the factors influencing it. IEA uses a decomposition analysis to show how each indicator influences the final energy consumption (Fig.1).

The Asia Pacific Research Center uses three types of indicators to describe energy efficiency: economic (value) indicators, technical and economic (physical) indicators and distribution indicators [25].

Economic indicators, including energy intensity, are defined as the ratio of energy consumption, measured in energy units (tons of oil equivalent [TOE]), to the indicator of economic activity, measured in monetary units in constant prices (GDP, value added, GRP, etc.).

Technical and economic indicators or physical indicators are calculated at the disaggregated level (at the level of the activity or end user) through the ratio of energy consumption to the indicator of the type of activity expressed in physical units (tonnes of steel, passenger-kilometers, etc.) or units of consumption (for example, for an engine, building, etc.). These technical and economic indexes are called the units of specific energy consumption. Thus, from a similar point of view, the energy efficiency of the sector is investigated in a number of works [32-37].

The required level of aggregation

The required level of intensity analysis

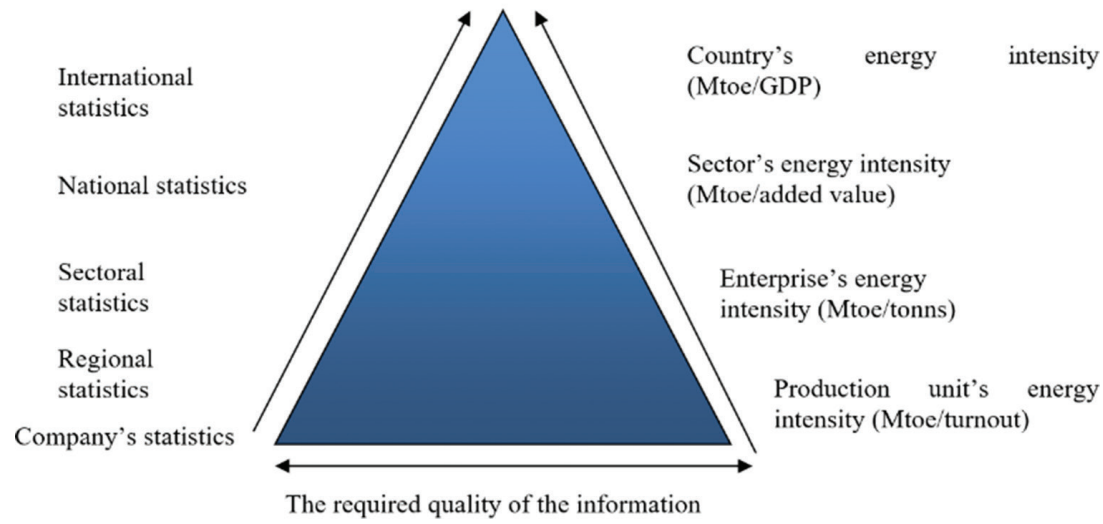

Figure 1: Pyramid of energy efficiency indicators. 
Morton et al. [38] examine the impact of socio-economic factors and national energy efficiency policies on key indicators and characteristics in the given area. To assess this impact, the authors employed spatial regression models of the dependence of energy efficiency factors on key indicators of socio-economic development, living conditions and geographical location of a territory. This approach takes into account the complex influence of various conditions and factors of spatial development on key characteristics of energy efficiency.

Selected works examine the household energy efficiency. The works of Barr et al. [39], Boardman [40], Brechling, Smith [41] and many others should be highlighted. However, despite the significance of such research, from our point of view, they significantly narrow the field of study, focusing only on one of the components of energy efficiency.

A number of studies examine the impact of energy market liberalization on energy efficiency policies. For example, the work of Nicolli and Vona [42] considers the impact of energy market liberalization on the development of renewable energy sources and state policy in this area.Agnolucci [43] evaluates the efficiency of wind power and the factors determining its development. Cadoret and Padovano in their research [44] analyze the driving forces of renewable energy sources' development and their impact on the economy's energy efficiency. At the same time, in our opinion, these studies are more likely aimed at creating mechanisms for managing energy efficiency and achieving target values in a given area, rather than at forming approaches for its assessment.

The issues of financing energy efficient technologies are also reflected in the works of many scientists and specialists. Thus, Geddes et al. [45] looked at the role of state-owned investment banks in financing low-carbon energy. Hall et al. [46-47] addressed the problems of investing in low-carbon projects and the formation of investment markets and institutions in this area. The issues of attracting private investment to finance energy efficient projects are reviewed by Mathews et al. [48] and many other scientists and practitioners. These works are also aimed at developing energy-efficient control mechanisms and the implementation of an energy efficiency policy. However, they only indirectly touch upon energy efficiency assessment issues.

A large number of works are devoted to assessing the impact of energy efficiency policies on the change of the energy consumption size and structure [49-51]. Thus, Moreau and Vuille [51] explore the role of structural changes and the effectiveness of energy efficiency measures in reducing energy consumption. Among the fundamental works in this direction, the research of Ang [52-54] is worthy of mention. In his work, Ang, first of all, assessed how measures in the field of energy efficiency affect energy consumption indicators, which is the basis for energy efficiency policies.

Summing up the analysis of modern approaches to the assessment and implementation of energy efficiency management mechanisms, it should be noted that in many cases only individual areas (components) of energy efficiency or some aggregated indicators (such as energy and power intensity and related indicators) are estimated. On the other hand, an integrated approach that takes into account the influence of various factors, as well as a detailed analysis of energy efficiency of technological cycles and processes, which is extremely important when evaluating and managing industrial complex energy efficiency, is missing in most of the works or investigations in general terms.

Taking into account the analytical review made earlier, the authors propose a methodological approach to assessing energy efficiency of processes in industrial complexes based on a phased three-level accounting of the following group of indicators: (i) indicators of energy efficiency and energy saving, (ii) indicators of economic efficiency of energy consumption, and (iii) indicators connected with the efficiency of using fixed assets and indicators of environmental efficiency of fuel and energy resources consumption. 
These groups of indicators are evaluated at the level of the industrial complex as a whole, at the level of the production and, finally, at the level of the technological process used for manufacturing products. In the proposed approach, the indicators calculated using energy consumption and power consumption both for primary energy resources and for secondary energy resources are taken into account. In the first case, authors do not separately allocate for the loss of electric and heat energy. If the calculation of energy and electrical capacity is carried out on secondary energy resources, then the indicator of the level of electric and heat energy losses becomes distinguishable.

Thus, the energy efficiency of an industrial complex can be assessed as a whole or one can carry out an analysis of each production process starting from the stage of preparing the fuel for the process and ending with the final product processing stage. This analysis will be the most comprehensive since each process will be considered separately and the possible influence of processes on each other will be eliminated.

\section{METHODOLOGY FOR ASSESSING THE ENERGY EFFICIENCY OF AN INDUSTRIAL COMPLEX}

To assess the energy efficiency of industrial complexes, the authors propose a system of indicators at three levels of the industrial complex:

1. The level of the industrial complex as a whole (E1).

2. The level of certain types of products manufactured in the industrial complex (E2).

3. The level of the technological process (E3).

The energy efficiency indicators of an industrial complex can be measured both as a whole and through analyzing each production process, starting from fuel preparation and ending with the final stage of product processing. Indicators for each level form a block structure.

The offered methodological approach uses indicators calculated for energy consumption and power consumption both for primary energy resources and for secondary energy resources. Energy efficiency indicators proposed by the authors for the level of the industrial complex as a whole are presented in Table 1. The composition and algorithms of calculating energy efficiency indicators are described in more detail in Ref. [55].

It should be noted that E1 is the most aggregated level and operates with summarized data of the production complex without their specification. At this level, it is difficult to carry out a detailed analysis, but at the same time, data at this level is the most accessible. Actually, the E1 level is the level of the summary analysis and identification of the main problems in the field of energy efficiency of the industrial complex. In addition, the assessment at this level shows the synthetic effect of events and projects implemented at industrial complex enterprises on its energy efficiency. Therefore, the E1 level is the most important for evaluating the results of the energy efficiency policy pursued by the industrial complex.

Level E2 is connected with the evaluation of energy efficiency of separate types of product manufacturing. Primarily this level is necessary to assess the efficiency of technological cycles used at the enterprises of the complex, and to carry out decisions in introducing the technical policy. In addition, the estimates obtained at the E2 level make it possible to compare the enterprises of the complex with the main competitors, assess their competitive positions and develop competitive development strategies. It should be noted that the data necessary for assessing energy efficiency indicators at this level is not always available. Often for obtaining such assessments an energy audit of the industrial complex and its enterprises 
Table 1: Energy efficiency indicators for an industrial complex as a whole (E1).

Indicator

1. Energy intensity of gross revenue (primary energy consumption), tonne of reference fuel/US dollars

2. Electric capacity of gross revenue (primary energy consumption), kWh/US dollars

3. Energy intensity of gross revenue (secondary energy consumption), tonne of reference fuel / US dollars

4. Electric capacity of gross revenue (secondary energy consumption), kWh/US dollars

5. Energy loss in the electrical grid of an industrial complex, $\%$

6. Heat loss in the heating network of an industrial complex, $\%$

7. The share of primary energy resources, produced from own renewable energy sources, in the total energy consumption of an industrial complex, $\%$

8. Specific energy consumption per production output

1. The share of the cost of fuel and energy resources in a gross revenue of industrial complex, \%

2 . The electric energy consumption anticipation index in relation to the production volume increase, $\%$

3. The primary energy resources consumption anticipation index in relation to the production volume increase, $\%$

4. The energy intensity of fixed assets of an industrial complex, tonne of reference fuel/ US dollars

5. The electric capacity of fixed assets of an industrial complex, $\mathrm{kWh} / \mathrm{US}$ dollars

6 . The share of the cost of energy saving measures in gross revenue of an industrial complex, \%

7. Integral indicator of energy saving potential by types of products

identified during the energy audit or comparison with the best values of specific energy consumption of similar products

1. The ratio of $\mathrm{CO}_{2}$ emissions to the primary energy resources consumption (in the whole industrial complex), tonne $\mathrm{CO}_{2}$ /tonne of reference fuel

2. The ratio of $\mathrm{CO}_{2}$ emissions to gross revenue of the industrial complex, tonne $\mathrm{CO}_{2} / \mathrm{US}$ dollars

3. The ratio of $\mathrm{CO}_{2}$ emissions to the primary electricity consumption (in the whole industrial complex), tonne $\mathrm{CO}_{2} / \mathrm{kWh}$

4. The ratio of $\mathrm{CO}_{2}$ emissions to the final consumption of energy resources (in the whole industrial complex), tonne $\mathrm{CO}_{2}$ /tonne of reference fuel

5. Carbon intensity of an industrial complex (integral indicator)

is required. Therefore, in many cases, the energy efficiency assessments of an industrial complex are limited only to level E1.

E3 level is a level of an even deeper energy analysis of industrial complex activities. In fact, at this level, the energy efficiency of the main technological processes of the complex is 
assessed. This makes it possible to most accurately identify "bottlenecks" in the processes, form the best solutions to the problems and suggest the appropriate measures and projects for the energy efficiency development of the industrial complex. At the same time, it is very difficult to obtain data for conducting assessments at level E3, and often it is not possible (for example, this may be associated with the installation of the complex or expensive measuring equipment). In addition, at this level, one can carry out the analysis of a very limited number of indicators. That is why in many cases the assessment at level E3 is not conducted.

It should also be noted that at levels E2 and E3, the estimates obtained for separate indicators (blocks of indicators) are not always equivalent (they have different weights in the formation of the resulting energy efficiency rating). Therefore, an important step in assessing energy efficiency at these levels is to assess the significance of separate blocks (energy efficiency indicators). To implement this step, the hierarchy analysis method is proposed for the calculations [55].

To obtain summarized (synthetic) estimates of an energy efficiency of an industrial complex, the use of hierarchy analysis method is proposed. The method implies dividing the problem into simpler component parts and further processing sequences using a pairwise comparison. As a result, the relative degree (intensity) of the interaction of elements in the hierarchy can be expressed. These results (judgments) are then expressed numerically. The method of analyzing the hierarchy includes procedures for synthesizing multiple judgments, obtaining priority criteria and finding alternative solutions [55].

In general terms, the following expression can be used to determine the resulting energy efficiency scores at $k$-level of assessment.

$$
E_{k}=\sum_{n=1}^{N} X_{k n} \cdot a_{n} ; \quad \sum_{n=1}^{N} a_{n}=1,
$$

where

$X_{k n}$ is the resulting (integral) evaluation of the energy efficiency of an industrial complex at the $k$-level over the $n$-block;

$N$ is the number of blocks of indicators according to which energy efficiency is assessed at the $k$-level;

$a_{n}$ - the weight index of the $n$-block in the formation of the integral energy efficiency assessment at the $k$-level.

Note that all indicators used to assess the energy efficiency of an industrial complex at different levels sometimes have incompatible measurement units. Therefore, to obtain an integrated energy efficiency estimation at each level, it is necessary to standardize the values of the individual indicators, i.e. reduce them to a dimensionless comparable form. The proposed approach to standardizing is as follows:

$$
a_{\mathrm{kns}}^{\text {stand }}=\frac{a_{\mathrm{kns}}}{a_{\mathrm{kns}, \text { ref }}},
$$

where

$a_{\mathrm{kns}}^{\text {stand }}$ is the standardized value of $s$-indicator included in block $n$ at the $k$-level of energy efficiency assessment;

$a_{k n s}$ is the current (actual) value of the $s$-indicator included in block $n$ at the $k$-level of energy efficiency assessment;

$a_{k n s, r e f}$ is the reference value of the $s$-indicator included in block $n$ at the $k$-level of energy efficiency assessment.

For reference values, the authors take the values of such indicators of the main competitors or the target values determined by the industrial complex development strategy. It should be 
noted that the problem of defining and justifying reference values of the industrial complex energy efficiency indicators is a separate and huge task that is solved individually for each specific complex and does not have an all-in-one approach to its solution.

During the assessment, two approaches are used to determine the reference values of energy efficiency indicators:

1. absolute values (energy efficiency indicators of main competitors or target values);

2. relative values: indicators for certain years are taken as reference indicators, or in accordance with the aforementioned methodology selective statistical characteristics of the variable-based series of these indicators are used.

If the total dispersion is chosen as a scale, the corresponding formula for the normalization of the indicator is:

$$
\tilde{X}_{i}=\frac{X_{i}-\bar{X}}{\sigma},
$$

where

$$
\sigma=\sqrt{\frac{1}{N} \sum_{i=1}^{N}\left(X_{i}-\bar{X}\right)^{2}}
$$

and

$$
\bar{X}=\frac{1}{N} \sum_{i=1}^{N} X_{i}
$$

The resulting estimates for the blocks of indicators can be calculated using the geometric mean value of the indicators included in the block:

$$
X_{k n}=\sqrt[Z]{\prod_{s=1}^{Z} \alpha_{k n s}^{\text {stand }}}
$$

where

$Z$ is the number of indicators included in block $n$ at the $k$-level of energy efficiency assessment.

According to a similar algorithm, the integral indicator of energy efficiency is determined at level $E_{1}$, in contrast to levels $E_{2}$ and $E_{3}$, where the integral indicators are determined in accordance with expression (1).

Within a three-level energy efficiency assessment, in addition to estimates at each level $E_{k}$, it is necessary to obtain an integral estimation of the $E_{\text {total }}$, combining assessments at all levels, which is the most objective integral criterion of the energy efficiency of the complex. However, it should be noted that estimates at levels $E_{2}$ and $E_{3}$ are not always available. In this case, the estimate of the $E_{\text {total }}$ will be the same as $E_{1}$.

The calculation of $E_{\text {total }}$ can be made using the following expression:

$$
E_{\text {total }}=\sqrt[M]{\prod_{m=1}^{M} E_{1}^{m}} \cdot K_{2} \cdot K_{3}
$$

where

$E_{1}^{m}$ is integrated assessment of energy efficiency at the 1st level, obtained for the enterprise of the $m$-industrial complex;

$M$ is the number of main enterprises that were used within an energy efficiency assessment of an industrial complex. It should be noted that with a large number of enterprises included 
in the industrial complex, the energy efficiency assessment can be carried out for separate representative enterprises, assuming that the estimates obtained for this sample of enterprises, in general, reflect the situation in the complex as a whole;

$K_{2}$ is the index taking into account the energy efficiency estimates obtained for level $E_{2}$;

$K_{3}$ is the index taking into account the energy efficiency estimates obtained for level $E_{3}$.

In turn, the values of $K_{2}$ and $K_{3}$ are determined from:

$$
K_{2}=\sum_{i=1}^{R} E_{2 \mathrm{i}} \cdot b_{i} ; \quad \sum_{i=1}^{R} b_{i}=1
$$

where

$E_{2 \mathrm{i}}$ is the resulting assessment of energy efficiency, obtained for the $i$-th type of products of an industrial complex;

$R$ - the number of the main types of products manufactured in the industrial complex;

$b_{i}$ - the proportion of the $i$-th type of product in gross revenue.

$$
K_{3}=\sum_{j=1}^{H} E_{3 \mathrm{j}} \cdot c_{j} ; \quad \sum_{j=1}^{h} c_{j}=1
$$

where

$E_{3 \mathrm{j}}$ is the resulting assessment of energy efficiency obtained for the $j$-th technological process in the industrial complex;

$H$ is the number of main technological processes used in the industrial complex;

$c_{j}$ is significance (weight) of the $j$-th technological process in the activities of the industrial complex. The values of $c_{j}$ are usually determined by an expert based on the analysis of the technologies and processes used in a particular industrial complex.

Summing up, the authors note that the proposed methodology for assessing the energy efficiency of an industrial complex contains the following main provisions:

1. calculation of energy efficiency indicators is carried out at the level of the industrial complex as a whole, at the level of its product manufacturing and at the level of the technological process used to create a certain type of product;

2. formation of the following blocks of indicators at each level: indicators of energy efficiency and energy saving, indicators of economic efficiency of energy consumption, indicators connected with the efficiency of using fixed assets and indicators of environmental efficiency of fuel and energy resources consumption;

3. consideration of the following main processes for industrial production: material preparation; production of semi-finished products; additional processing; final processing;

4. calculation of indicators using energy consumption and power consumption for both primary energy resources and secondary energy resources;

5. consideration of green economy indicators (greenhouse gas emissions, emissions of pollutants, etc.) when assessing the prospects for growth in energy consumption;

6. assessment of the significance of separate blocks (energy efficiency indicators) using the hierarchy analysis method.

Thus, the proposed methodological tool makes it possible to evaluate the energy efficiency indicators of the industrial complex as a whole and to analyze each production process, starting from fuel preparation for the process and ending with the final processing of the product. Such an analysis is especially valuable since each process is considered separately and the possible influence of the processes on each other is eliminated. 


\section{ENERGY EFFICIENCY EVALUATION OF INDUSTRIAL COMPLEXES \\ SPECIALIZED IN COPPER PRODUCTION AND COPPER-BASED PRODUCTS}

In this paper, the authors analyzed the energy efficiency of world's leading copper producers such as the Ural Mining and Metallurgical Company (UMMC) and competing enterprises also engaged in the production of copper and other non-ferrous metals.

UMMC is a vertically integrated company, which unites enterprises of the mining, metallurgical, metal-working complex, as well as the construction industry, and is located mainly in Russia and neighboring countries. All of them are integrated into one technological chain. The company's head office is located in the town of Verkhnyaya Pyshma in the Sverdlovsk Region.

The company uses a closed technological chain for copper production: from the extraction of raw materials to the production of finished copper-based products (copper wire rod, rolled products, cable products, heat exchangers). The management of UMMC's key assets is handled by UMMC Holding LLC. The consolidated revenue of UMMC group in 2016 was $\$ 5.3$ billion, with annual investments in the development of production amounting to over $\$ 1$ billion. The UMMC employs more than 80,000 people.

The main Russian competitors of UMMC are the Norilsk Nickel (Nor Nickel) and the Russian Copper Company (RCC). Outside Russia, the Russian companies have to compete with the following companies: Freeport-McMoRan Copper \& Gold Inc.(USA), Glencore Xstrata Plc (Switzerland), Codelco (Chile), BHP Billiton (Australia and Britain), Jiangxi Copper (China), Southern Cooper Corp., KGHM Polska Miedz SA (Poland), VALE and others.

A comparative analysis of the energy efficiency of the considered companies was carried out according to four main indicators at the $E_{1}$ level, namely:

1. energy intensity of gross revenue (primary energy consumption), gr. of reference fuel/ US dollars;

2. electric capacity of gross revenue, $\mathrm{kWh} / \mathrm{US}$ dollars;

3. energy intensity of fixed assets of an industrial complex, gr. of reference fuel/US dollars;

4. electric capacity of fixed assets of an industrial complex, $\mathrm{kWh} / \mathrm{US}$ dollars.

The data on UMMC enterprises were divided into three types of activities: (i) mining and preparation of ore, (ii) processing of ore and (iii) production of refined copper, wire rod, copper ingots, etc. Representative enterprises for each type of activity were selected that make the largest contribution to gross revenue by type of activity, as well as having comparable data for calculating energy efficiency indicators.

For the "Mining and preparation of ore" activity, energy efficiency indicators were calculated for the Gai mining and processing plant. For the "Processing of ore" activity energy efficiency indicators were calculated for OAO Svyatogor and OAO SredneUralsky copper plant. For "Production of refined copper, wire rod, copper ingots, etc." activity energy efficiency indicators were calculated for Uralelectromed JSC, Electronic JSC, Kirovsky Non-Ferrous Metals Processing Plant, Revdinsky Plant.

The analysis of energy efficiency indicators of UMMC was carried out in comparison with the four leading competing companies: Codelco, Glencore International AG, Vedanta Resources and KGHM Polska Miedz SA. Energy efficiency indicators of Norilsk Nickel were also calculated for comparison. The aggregated indicators for relevant types of activities were calculated as weighted averages, where the weights were determined by the share of the primary energy consumption of the enterprise in the total energy consumption by the selected 
Table 2: Comparison of the leading copper manufacturers by the indicators "Energy intensity of gross revenue" (by primary energy consumption) and "electric capacity of gross revenue" (by primary energy consumption).

\begin{tabular}{llllll}
\hline & 2012 & 2013 & 2014 & 2015 & 2016 \\
\hline Energy intensity of gross revenue (gr. of ref. fuel/US dollars) & & & \\
\hline UMMC, mining and preparation of ore & 271.5 & 283.2 & 479.5 & 418.0 & 495.3 \\
UMMC, processing of ore & 656.7 & 790.2 & 1247.2 & 1173.9 & 931.4 \\
UMMC, copper production & 856.2 & 936.9 & 1592.5 & 1848.2 & 1467.7 \\
Norilsk Nickel & 709.1 & 834.2 & 824.2 & 1069.3 & 1113.0 \\
Glencore International AG & 195.8 & 101.1 & 111.5 & 146.0 & 141.0 \\
Vedanta Resources & 769.2 & 778.5 & 919.9 & 1235.7 & 1313.6 \\
KGHM Polska Miedz SA & 104.4 & 134.2 & 150.3 & 190.0 & 116.0 \\
Codelco & 104.9 & 108.3 & 115.7 & 142.6 & 152.2 \\
\hline Electric capacity of gross revenue (kWh / USD) & & & & \\
\hline UMMC, mining and preparation of ore & 798.2 & 865.1 & 1542.2 & 1746.1 & 2059.2 \\
UMMC, processing of ore & 962.2 & 1166.3 & 1903.1 & 1482.8 & 1155.8 \\
UMMC, copper production & 1166.9 & 1127.6 & 1834.8 & 2162.3 & 1823.4 \\
Norilsk Nickel & 778.3 & 846.1 & 872.7 & 1207.5 & 1157.3 \\
Glencore International AG & 74.5 & 38.8 & 31.4 & 37.2 & 35.2 \\
Vedanta Resources & 253.1 & 263.6 & 273.0 & 373.6 & 481.7 \\
KGHM Polska Miedz SA & 60.1 & 74.2 & 84.3 & 98.0 & 96.3 \\
Codelco & 52.6 & 48.5 & 49.7 & 50.1 & 52.6 \\
\hline
\end{tabular}

enterprises by type of activity. Indicators were calculated in the Russian currency and purchasing power parity (PPP) compared with foreign competitors (Table 2).

As shown by the calculations, the indicators "Energy intensity of a gross revenue (primary energy consumption) (gr. of reference fuel/US dollars)" and "Electric capacity of a gross revenue (kWh/US dollars)" by UGMK significantly exceed the performance of foreign companies, including Codelco, the world leader in copper production. The values of these indicators for UMMC are closest to the values of Norilsk Nickel; however, UMMC indicators do not have stability in the considered time range.

The value of the index "Electric capacity of fixed assets of industrial complex (kWh/US dollars)" at UMMC is several times higher than at Norilsk Nickel.

Summing up the assessment and analysis of individual indicators of energy efficiency of the UMMC and other enterprises, the following points can be noted:

1. As a negative trend, the authors highlight the increase in energy intensity of the activities "Mining and preparation of ore" and "Production of refined copper, wire rod, copper ingots, etc." during the period 2010-2016.

2. As a certain positive trend, the authors observe a slight decrease in the indicators of energy intensity and electrical intensity of gross revenues in terms of primary power con- 
sumption by the type of activity "Ore processing". The authors also indicate a positive trend in almost all the indicators for all distinguished activities of UMMC during 2016. However, it is too early to talk about a radical change in the current trend.

3. Primary energy consumption has a great influence on energy efficiency indicators since this indicator is included in the calculation of all energy efficiency indicators taken into account in the assessment.

4. As regards the indicator "The electric energy consumption anticipation index in relation to production volume increase," in most cases, the electricity consumption is growing faster than gross revenue, which can be characterized as a negative trend requiring the implementation of energy-saving measures (first of all, in relation to electricity).

It can be said that the obtained results do not correspond with Russia's current energy strategy where new requirements have been formulated in the context of the changed economic and energy policy. It is clear that it will be difficult to achieve the desired indicators of economic development if the current specific energy intensity of the economy is maintained in the future. In this regard, the Russian Federation government has enacted a number of legislations designed to change the situation: implementing requirements for the construction of industrial facilities, operating equipment in accordance with best available technologies and world standards, introducing financial instruments for promoting energy efficiency, and developing the market for "white certificates" and energy service agreements, etc.

Taking into consideration the rising cost of energy resources, it is clear that reducing the cost of electricity and primary energy resources is an important task for Russian industrial complexes, including UMMC. As a result, the analysis of energy costs in the technological production cycles of UMMC is necessary to improve the energy efficiency performance and competitiveness of products in the global market.

\section{DISCUSSION}

The comparative analysis revealed significant differences in the values of the energy efficiency indicators of the UMMC and competing foreign enterprises.

First of all, the reason for this discrepancy is obvious: the analysis of foreign competitors and Norilsk Nickel was carried out on the entire complex as a whole rather than according to the synthetic indicators of certain types of activity calculated by using weighted indexes. This disadvantage can be eliminated upon the availability of relevant information about the indicators of activities of foreign competitors.

Second, the values of energy intensity indicators depend on the specific technology used, industry, region, and country. Such aspects in most cases are quite difficult to consider.

Third, the annual reports of UMMC competitors to a greater extent present data on greenhouse gas emissions, rather than data on the consumption of energy resources; in particular, the annual reports of KGHM Polska Miedz SA provide data on the carbon intensity of a ton of produced copper. This deficiency can be easily eliminated if the relevant data from the UMMC is necessarily taken into account.

In the Russian industry, the system of hidden (technological) and cross (social) subsidies in the energy sector also plays an important role in low motivation for energy saving when costs are transferred from one type of energy product to another.

Fourth, the reduction in energy intensity does not always result in benefits for the enterprise, since the introduction of energy-efficient technologies is associated with additional investments in new equipment, the returns from which do not always cover costs. In most 
cases, the introduction of energy-efficient technologies in relation to old equipment is economically unprofitable, as a result of which production stops and jobs are lost.

The most intense competition in the Russian copper market is for the supply of raw materials. At the current price, competition is virtually absent due to the fact that the price of copper and copper products is determined by the London Metal Exchange.

However, the above-described differences in the values of the energy efficiency indicators of the UMMC and foreign companies cannot be "justified". Unfortunately, the lower values of energy efficiency compared to foreign competitors are characteristic of many Russian industrial companies, including producers of nonferrous materials.

\section{CONCLUSIONS}

Summing up, the authors emphasize that the energy management of industrial enterprises and industrial complexes should be carried out with the intent to improve energy efficiency to ensure sustainable socio-economic development of industrial enterprises, industrial complexes and the country as a whole.

In general, the results of practical testing have shown that the proposed methodological tool for assessing the energy efficiency of an industrial complex can be used to solve practical problems associated with a comprehensive analysis of the energy consumption rationality and opportunities for improving the energy efficiency of industrial complexes. Also, the given methodological tool may aid strategic development of the complex and its constituent enterprises in new conditions determined by the transition of socio-economic systems to a green economy. The main advantages of the methodological tool are the integrated consideration of various factors influencing energy efficiency, its flexibility, the ability to analyze energy efficiency with the desired scope, depth and detail, which allows making appropriate management decisions.

As further research directions, the authors point to two major areas:

1. Conducting practical studies of energy efficiency of the largest Russian and world industrial complexes, specializing in various types of activities, and identifying the sustainable trends and patterns in the determination of energy efficiency indicators.

2. Modeling and validation of various factors that influence the integrated indicators of energy efficiency of industrial complexes.

\section{REFERENCES}

[1] Brown, L.R., Eco-Economy Building an Economy for the Earth, Great Britain: London, p. 352, 2001.

[2] Bina, O., The green economy and sustainable development: an uneasy balance? Environment and Planning C: Government and Policy, 31(6), pp. 1023-1047, 2013. https:// doi.org/10.1068/c1310j

[3] Towards a green economy: Pathways to sustainable development and Poverty Eradication; United Nations Environment, Online, https://sustainabledevelopment.un.org/content/documents/126GER_synthesis_en.pdf (accessed on 30 May 2019).

[4] The Future We Want: Resolution Adopted by the General Assembly United Nation; United Nations, Online, http://daccess-ods.un.org/access.nsf/Get?Open\&DS=A/ RES/66/288\&Lang=E (accessed on 03 June 2019).

[5] Towards green growth: A summary for policy makers; OECD, Online, https://www. oecd.org/greengrowth/48012345.pdf (accessed on 01 June 2019). 
[6] Rethinking the Economic Recovery: A Global Green New Deal; UNEP, Online, http://wedocs.unep.org/bitstream/handle/20.500.11822/7727/-Rethinking\%20the\%20 Economic\%20Recovery_\%20A\%20Global\%20Green\%20New\%20Deal-2009853. pdf? sequence $=2 \&$ isAllowed=y (accessed on 05 June 2019).

[7] The transition to a Green Economy: Benefits, Challenges and Risks from a Sustainable Development Perspective; United Nations Environment, Online, https://www.unenvironment.org/resources/report/transition-green-economy-benefits-challenges-and-riskssustainable-development (accessed on 01 June 2019).

[8] Decoupling natural resource use and environmental impacts from economic growth, A Report of the Working Group on Decoupling to the International Resource Panel; UNEP, Online, http://wedocs.unep.org/bitstream/handle/20.500. 11822/9816/-Decoupling\%3a\%20natural\%20resource\%20use \%20and\%20environmental\%20impacts\%20from\%20economic\%20growth\%20-2011Decoupling_1. pdf? sequence $=3 \&$ isAllowed $=y$ (accessed on 05 June 2019).

[9] Vuuren, V., Detlef, P., et al., Energy, land-use and greenhouse gas emissions trajectories under a green growth paradigm. Global Environmental Change, 42, pp. 237-250, 2017.

[10] De Vries, B., et al., Greenhouse gas emissions in an equity-, environment-and serviceoriented world: an IMAGE-based scenario for the 21st century. Technological Forecasting and Social Change, 63(2-3), pp. 137-174, 2000. https://doi.org/10.1016/ s0040-1625(99)00109-2

[11] Holdren, J.P., Energy and sustainability. Science, 315(5813), p. 737, 2007. https://doi. org/10.1126/science. 1139792

[12] Green Growth, Resources and Resilience. Environmental Sustainability in Asia and the Pacific; UNESCAP, ADB, UNEP, Online, https://www.unescap.org/sites/default/files/ GGRR_Full-Report_0.pdf (accessed on 05 June 2019).

[13] Low Carbon Green Growth Roadmap for Asia and the Pacific-turning resource constraints and the climate crisis in to economic growth opportunities; UNESCAP, Online, https://www.unescap.org/sites/default/files/Full-report.pdf (accessed on 07 June 2019).

[14] Green Growth and Climate Resilience. National Strategy for Climate Change and Low Carbon Development; Kigali, Republic of Rwanda, Online, https://www.greengrowthknowledge.org/sites/default/files/downloads/policy-database/RWANDA\%29\%20 Green $\% 20$ Growth $\% 20$ and $\% 20$ Climate $\% 20$ Resilience $\% 20-\% 20$ National $\% 20$ Strategy\%20for\%20Climate\%20Change\%20and\%20Low\%20Carbon\%20Development. pdf (accessed on 07 June 2019).

[15] Annual Energy Outlook 2019 (AEO2019); EIA, Online, https://www.eia.gov/outlooks/ aeo/pdf/aeo2019.pdf (accessed on 11 June 2019).

[16] Energy intensity, in OECD Factbook 2015-2016: Economic, Environmental and Social Statistics; OECD, Online, https://www.oecd-ilibrary.org/docserver/factbook2015-40-en.pdf?expires $=1562016128 \& \mathrm{id}=\mathrm{id} \&$ accname $=$ guest $\&$ checksum $=27 \mathrm{~B} 0 \mathrm{~B} 9 \mathrm{E}$ FBA40AED7993B2E7CA381EA42 (accessed on 11 June 2019).

[17] Energy Strategy of Russia for the period up to 2030; Institute of Energy Strategy, Online, http://www.energystrategy.ru/projects/docs/ES-2030_(Eng).pdf (accessed on 11 June 2019).

[18] Chiogioji, M.H., Industrial energy conservation, Marcel Dekker, Inc: USA, p. 260, 1979.

[19] Grübler, A., Jefferson, M. \& Nakićenović, N., Global energy perspectives: A summary of the joint study by the International Institute for Applied Systems Analysis and World 
Energy Council. Technological Forecasting and Social Change, 51(3), pp. 237-264, 1996. https://doi.org/10.1016/0040-1625(95)00251-0

[20] Energy Efficiency: A Recipe for Success; World Energy Council, Online, https://www. worldenergy.org/wp-content/uploads/2012/10/PUB_Energy_Efficiency_A_Recipe_ For_Success_2010_WEC.pdf (accessed on 06 June 2019).

[21] Boyd, G., McDonald, J.F., Ross, M. \& Hanson, D.A., Separating the changing composition of US manufacturing production from energy efficiency improvements: a Divisia index approach. The Energy Journal, 8(2), pp. 77-96, 1987. https://doi.org/10.5547/ issn0195-6574-ej-vol8-no2-6

[22] Ang, B.W. \& Lee, S.Y., Decomposition of industrial energy consumption: some methodological and application issues. Energy Economics, 16(2), pp. 83-92, 1994. https:// doi.org/10.1016/0140-9883(94)90001-9

[23] Ang, B.W. \& Choi, K.H., Decomposition of aggregate energy and gas emission intensities for industry: a refined Divisia index method. The Energy Journal, 18(3), pp. 59-73, 1997. https://doi.org/10.5547/issn0195-6574-ej-vol18-no3-3

[24] Ang, B.W., Zhang, F.Q. \& Choi, K.H., Factorizing changes in energy and environmental indicators through decomposition. Energy, 23(6), pp. 489-495, 1998. https://doi. org/10.1016/s0360-5442(98)00016-4

[25] Energy Efficiency Indicators: A Study of Energy Efficiency Indicators for Industry in APEC Economies; Asia Pacific Energy Research Centre, Online, https://aperc.ieej. or.jp/file/2010/9/26/Energy_Efficiency_Indicators_for_Industry_2000.pdf （accessed on 07 June 2019).

[26] Energy Policies of IEA Countries; International Energy Agency, Online, http://www. iea.org/publications/freepublications/publication/Canada2009.pdf (accessed on 10 June 2019).

[27] Unander, F., Energy indicators and sustainable development: the International Energy Agency approach. Natural Resources Forum, 29(4), pp. 377-391, 2005. https://doi. org/10.1111/j.1477-8947.2005.00148.x

[28] Taylor, P.G., d'Ortigue, O.L., Francoeur, M. \& Trudeau, N., Final energy use in IEA countries: The role of energy efficiency. Energy Policy, 38(11), pp. 6463-6474, 2010. https://doi.org/10.1016/j.enpol.2009.05.009

[29] Energy Statistics Manual; OECD/IEA, Online, https://www.iea.org/publications/ freepublications/publication/statistics_manual.pdf (accessed on 06 June 2019).

[30] Energy Indicators System: Index Construction Methodology; EERE, Online, https:// www.energy.gov/sites/prod/files/2015/06/f24/index_methodology.pdf (accessed on 09 June 2019).

[31] World Energy Perspective. Energy Efficiency: A straight path towards energy sustainability; World Energy Council, Online, https://www.worldenergy.org/wp-content/ uploads/2016/10/EnergyEfficiencyAStraightPathFullReport.pdf (accessed on 09 June 2019).

[32] Worrell, E., et al., Energy intensity in the iron and steel industry: a comparison of physical and economic indicators. Energy policy, 25(7-9), pp. 727-744, 1997. https://doi. org/10.1016/s0301-4215(97)00064-5

[33] Worrell, E., Price, L. \& Martin, N., Energy efficiency and carbon dioxide emissions reduction opportunities in the US iron and steel sector. Energy, 26(5), pp. 513-536, 2001. https://doi.org/10.1016/s0360-5442(01)00017-2 
[34] Tan, X., Li, H., Guo, J., Gu, B. \& Zeng, Y., Energy-saving and emission-reduction technology selection and $\mathrm{CO} 2$ emission reduction potential of China's iron and steel industry under energy substitution policy. Journal of Cleaner Production, 222, pp. 823-834, 2019. https://doi.org/10.1016/j.jclepro.2019.03.133

[35] Bhadbhade, N., Zuberi, M.J.S. \& Patel, M.K., A bottom-up analysis of energy efficiency improvement and $\mathrm{CO} 2$ emission reduction potentials for the swiss metals sector. Energy, 181, pp. 173-186, 2019. https://doi.org/10.1016/j.energy.2019.05.172

[36] Price, L., Sinton, J., Worrell, E., Phylipsen, D., Xiulian, H. \& Ji, L., Energy use and carbon dioxide emissions from steel production in China. Energy, 27(5), pp. 429-446, 2002. https://doi.org/10.1016/s0360-5442(01)00095-0

[37] Gielen, D. \& Moriguchi, Y., CO2 in the iron and steel industry: an analysis of Japanese emission reduction potentials. Energy policy, 30(10), pp. 849-863, 2002. https://doi. org/10.1016/s0301-4215(01)00143-4

[38] Morton, C., Wilson, C. \& Anable, J., The diffusion of domestic energy efficiency policies: A spatial perspective. Energy Policy, 114, pp. 77-88, 2018. https://doi.org/ 10.1016/j.enpol.2017.11.057

[39] Barr, S., Gilg, A.W. \& Ford, N., The household energy gap: examining the divide between habitual- and purchase-related conservation behaviours. Energy Policy, 33(11), pp. 1425-1444, 2005. https://doi.org/10.1016/j.enpol.2003.12.016

[40] Boardman, B., New directions for household energy efficiency: evidence from the UK. Energy Policy, 32(17), pp. 1921-1933, 2004. https://doi.org/10.1016/j. enpol.2004.03.021

[41] Brechling, V. \& Smith, S., Household energy efficiency in the UK. Fiscal Studies, 15(2), pp. 44-56, 1994. https://doi.org/10.1111/j.1475-5890.1994.tb00196.x

[42] Nicolli, F. \& Vona, F., Energy market liberalization and renewable energy policies in OECD countries. Energy Policy, 128, pp. 853-867, 2019. https://doi.org/10.1016/j. enpol.2019.01.018

[43] Agnolucci, P.A., Wind electricity in Denmark: a survey of policies, their effectiveness and factors motivating their introduction. Energy Policy, 11, pp. 951-963, 2007. https:// doi.org/10.1016/j.rser.2005.07.004

[44] Cadoret, I. \& Padovano, F., The political drivers of renewable energies policies. Energy Economics, 56, pp. 261-269, 2016. https://doi.org/10.1016/j.eneco.2016.03.003

[45] Geddes, A., Schmidt, T.S. \& Steffen, B., The multiple roles of state investment banks in low-carbon energy finance: an analysis of Australia, the UK and Germany. Energy Policy, 115, pp. 158-170, 2018. https://doi.org/10.1016/j.enpol.2018.01.009

[46] Hall, S., Foxon, T.J. \& Bolton, R., Investing in low-carbon transitions: energy finance as an adaptive market. Climate Policy, 17(3), pp. 280-298, 2017. https://doi.org/10.10 80/14693062.2015.1094731

[47] Hall, S., Foxon, T.J. \& Bolton, R., Financing the civic energy sector: how financial institutions affect ownership models in Germany and the United Kingdom. Energy Research \& Social Science, 12, pp. 5-15, 2016. https://doi.org/10.1016/j.erss.2015.11.004

[48] Mathews, J.A., Kidney, S., Mallon, K. \& Hughes, M., Mobilizing private finance to drive an energy industrial revolution. Energy Policy, 38, pp. 3263-3265, 2010. https:// doi.org/10.1016/j.enpol.2010.02.030

[49] Moreau, V., De Oliveira Neves, C.A. \& Vuille, F., Is decoupling a red herring? The role of structural effects and energy policies in Europe. Energy Policy, 128, pp. 243-252, 2019. https://doi.org/10.1016/j.enpol.2018.12.028 
[50] Marrero, G. \& Ramos-Real, F. Activity sectors and energy intensity: decomposition analysis and policy implications for European countries (1991-2005). Energies, 6(5), pp. 2521-2540, 2013. https://doi.org/10.3390/en6052521

[51] Moreau, V. \& Vuille, F., Decoupling energy use and economic growth: counter evidence from structural effects and embodied energy in trade. Applied energy, 215, pp. 54-62, 2018. https://doi.org/10.1016/j.apenergy.2018.01.044

[52] Ang, B.W., The LMDI approach to decomposition analysis: a practical guide. Energy Policy, 33, pp. 867-871, 2005. https://doi.org/10.1016/j.enpol.2003.10.010

[53] Ang, B.W., Decomposition analysis for policymaking in energy: which is the preferred method? Energy Policy, 32, pp. 1131-1139, 2004. https://doi.org/10.1016/s0301-4215 (03)00076-4

[54] Bin, S. \& Ang, B.W., Structural decomposition analysis applied to energy and emissions: some methodological developments. Energy Economics, 34(1), pp. 177-188, 2012. https://doi.org/10.1016/j.eneco.2011.10.009

[55] Krivorotov, V.V., et al., Otsenka energoeffektivnosti proizvodstvennykh kompleksov kak osnova ikh konkurentosposobnogo razvitiya, YUNITI-DANA: Moscow, Russia, p. 146, 2018. 